UDC 338:631.1(477)

DOI 10.35433/ISSN2410-3748-2020-1(26)-3

JEL Classification: F55, I15, Q02, Q18

Klimova Inna

PhD, Senior Lecturer

Department of Economics, Management and Marketing

Zhytomyr Ivan Franko State University

Ukraine

ORCID 0000-0001-7412-379X

\title{
FOOD SECURITY IN UKRAINE AND THE WORLD DURING A PANDEMIC
}

The article addresses the issue of food security from an economic standpoint, its main components are defined and characterized, the importance of its development is proved. The provision of food products is proved to be a central element of food security, four constituents of its structure are emphasized. The provision of food products is identified in three forms. Physical provision implies easy availability of essential products in the consumer market, economic provision includes the financial ability to obtain, and social provision defines minimal differentiation in consumption of major product groups among various segments of the population.

It has been found out that exploring possibilities of improving the living standard as well as solving practically all key functioning problems of the agro-industrial complex are focused on providing the population of the country with food. In this regard, food security holds a significant place in the life support of the society, since food availability serves as an essential condition for human livelihood. The basic mechanisms used by the state to ensure food security are discussed. Favorable conditions, under which stable food security of the country and the region is possible, have been established.

The definition of the country's food security at the macroeconomic and microeconomic levels is presented. National features and threats to the impact of food security are reviewed.

It has been discussed that biological balancing, physical and economic food provision are crucial factors when ensuring individual and family food security for citizens of the country, regions, households and society as a whole. The main issues that may or already occur during quarantine are outlined along with the problems that agrarian manufacturers may face in a pandemic.

Keywords: food security, availability of food projects, agricultural products, principles of food security formation, coronavirus. 


\section{ПРОДОВОЛЬЧА БЕЗПЕКА В УКРАЇНІ ТА СВІТІ В УМОВАХ ПАНДЕМЇ̈}

У статті розглянуто проблему продовольчої безпеки з економічної точки зору, визначено та охарактеризовано основні ії складові, доведено необхідність їі розвитку.

Доведено, щз иентральним елементом продовольчої безпеки є забезпеченість

продуктами харчування, а в їі структурі варто виділити чотири складові.

Доступність продуктів харчування виявляється у трьох формах. Фізична доступність передбачає просту наявність на споживчому ринку життєво необхідних продуктів, економічна доступність включає фінансову можливість їх отримати, а соціальнамінімальну диференціацію у спожсиванні головних груп продуктів серед різних верств населення.

3'ясовано, щуо на забезпечення населення краӥни продуктами харчування орієнтоване рішення практично всіх ключових проблем функиіонування агропромислового комплексу

i вишукування можливостей підвищення рівня життя населення. У зв'язку з ции продовольча безпека займає особливе місие в життєзабезпеченні суспільства, оскільки наявність продовольства служить базовою умовою життєдіяльності людини.

Розглянуто основні механізми, що використовує держава для забезпечення продовольчої безпеки. Встановлено сприятливі умови, за яких можсливе стабільне забезпечення продовольчої безпеки краӥни та регіону.

Подано визначення продовольчої безпеки країни на макроекономічному та мікроекономічному рівнях. Розглянуто національні особливості продовольчої безпеки та загрози на ї̈ вплив.

3'ясовано, щзо біологічна збалансованість, фізична й економічна доступність продуктів харчування є важливими чинниками для забезпечення родинної та персональної продовольчої безпеки населення, для окремих громадян краӥни, домогосподарств, регіонів та суспільства в ијілому. Вказано основні проблеми, які можуть виникати або виникають під час карантинних заходів Розглянуто основні проблеми, з якими можуть зіштовхнутися виробники аграрної продукиії в умовах пандемії.

Ключові слова: продовольча безпека, доступність продуктів харчування, аграрна продукиія, принциии формування продовольчої безпеки, корона вірус.

Formulation of the problem. The problem of providing food security in the world is extremely relevant since there is a mismatch between food production and consumption, which means that the world is experiencing overproduction in developed countries and malnutrition in least developed countries. The United Nations General Assembly Resolution, adopted September $25^{\text {th }} 2015$, announces 17 Sustainable Development Goals for the period of time up to the year of 2030. According to the document, the task of overcoming poverty and hunger, ensuring food security and healthy lifestyles along with improving nutrition and promoting sustainable agriculture is 
prioritized [1]. This proves that the threat of a humanitarian crisis still remains the main challenge for the present-day world. The socio-political cataclysms of the African and Eurasian continents should not be forgotten as well. They have created tension in the world economy and have made certain alterations to the work of international organizations and institutions aimed to provide the necessary level of food security in the world.

This situation also concerns Ukraine, as our country is not a member of any of the world`s leading economic entities. In spite of Ukraine being an agrarian country, the export of agricultural products implements mainly through transnational corporations without long-term contracts, which could guarantee effective cooperation, first of all, in the field of agro-industrial complex, state food security and rational use of available resources for agricultural production and its processing.

Therefore, Ukraine has faced the obligation to modernize the state policy on the development of the agricultural industry, hence our state`s rank in the world food production will be established.

The purpose of the article is to summarize the main issues and ways of achieving food security while also to define fundamental directions of its provision and promotion.

Analysis of recent research and publications. A large number of works written by both domestic and foreign economists is devoted to the issue of food security. Some of those specialists are: N.V. Volchenko [2], P.I. Haidutsky [3], R.M. Kuzio [4], V.V Lypchuk [5], B.Y. Paskhaver [6], P.T. Sabluk [7], H.V. Syrotyuk [8] and others. They investigated theoretical aspects of food security and its structure, assessment methods. However, a number of issues remain unresolved: they require further research and development of ways and instruments for increasing the country`s food security and its guarantee at a higher level. 
Presenting the main material. According to the draft Law of Ukraine "On food security of Ukraine", food security is a socio-economic and environmental status in a country, in which all its citizens are steadily provided with food in the demanded quantity, range and corresponding quality that maintains the highest level of their physical and mental health [9]. At the same time, there are adequate resources, mechanisms and potential for permanent preservation of this status mainly by the state`s own forces for all segments of the population, regardless of external and internal factors and in the condition of maintaining a favorable environmental status. Based on the definition above, an indicator system has been developed to help determine the food security of both the region and the country as a whole [3, p.4].

In recent years, the provision of quality food to the population has significantly improved in most countries of the world, but this does not concern Ukraine. Moreover, Ukraine faces the problem of malnutrition. Much of the population does not have the ability to buy the necessary for an active and healthy lifestyle amount of food, some may even consume nothing but cheap products without receiving the mandatory volume of calories. By the mid-1990s, Ukraine had lost half of the pre-crisis level of meat consumption. Since then, this index cannot be increased [10].

A complete and realistic food security system in Ukraine should cover such components as robust and reliable supply, which is based on national agroindustrial complex and is capable to continuously provide the population with food at a proper level while adequately responding to the food market conjuncture; the physical and economic availability of the obligatory food quantity and range for different categories of the population is ensured by their solvency, which does not jeopardize the fulfilment of other basic human needs; the protection system of domestic food production from the import dependence both in food and resource provision. 
The state`s food security is the degree of providing the population with environmentally friendly and healthy food products of domestic production at scientifically reasonable standards and affordable prices while preserving and improving the living environment. Food plays a crucial role in human vital activity. Experts believe that during the life of the modern generation, the food issue may escalate into a deep international crisis [10].

The provision of food security is an ongoing issue in countries with low economic development level and developed countries that are constantly enhancing their food security mechanisms as well. State`s food security at a macroeconomic level is, despite the possible circumstances, a guaranteed provision of the complete necessary food set. At the macroeconomic level, it is an individual's confidence in being able to satisfy, using available sources, their and their family`s physiological needs for food. But this is achievable only on condition of on-farm manufacturing or production at the agro-industrial complex enterprises of the competitive countries [3, p.116].

There are four main measures of food security.

1. Availability. Its measurement reflects the quantity, quality and variety of food. Indicators of availability assessment are: energy sufficiency of the nutrition; the share of energy value provided by grain, root corps and tubers; average volume of obtained proteins; average volume of obtained proteins of animal origin; average volume of food production.

2. Access. Its measurement includes the indicators of: physical accessibility and infrastructure; economic affordability, which is characterized by a domestic food price index; the extent of malnutrition.

3. Stability. It is a temporary determinant of the food security. Stability measurement is separated in two groups: the first group includes various indicators that define risk factors; the second group is described as indicators of periodic upheavals such as fluctuations in the food supply on the domestic market or political instability. 
4. Utilization. Its measurement is also divided in two groups: the first group consists of variables that determine the food utilization, in particular, the indicators of access to water and hygiene languages; the second group contains indicators which characterize the end results of food misutilization [8, p.64].

National food security is affected by the emerging hazards. They include:

- deficiency of the quality control system

- $\quad$ reduction of the population purchasing power

- $\quad$ unbalanced food consumption by the population

- $\quad$ augmentation of the prices for agricultural products

- $\quad$ low consumption of animal products, loss of livestock

- $\quad$ import dependency on distinct food products etc.

The existence of these hazards raises the need for public administration to maintain a sufficient level of food security in the country. The process of managing food security must consist of continuous governmental influence. To achieve that, it is necessary to use such instruments as insurance, crediting, subsidization and others [8, p.64].

Certain concepts of formation are ordinary for the food security system. The core concept is the principle of sociality. It envisages the targeting of this system and each of its components for the satisfaction of human nutritional needs. The second important principle is complexity, meaning simultaneous impact on all constituent systems. The next principle is a systematic approach that involves a comprehensive manner to solving economic, social, environmental and other aspects of the food security issue. Another important concept is the adequacy in the selection of regulators, which is related to the ambiguity of their performance in different development states of the economic system and in the conditions of conjuncture change in the domestic and foreign markets. 
The last principle is the system stability - mandatory observance of the principles of sociality, complexity, systematicity and adequacy mentioned above, regardless of changes in the external environment [11, p.112].

Having evaluated the current status of food security, we can distinguish a number of positive characteristics, namely: the formation of market infrastructure (a system of wholesale food markets and marketing information); income augmentation; the increase in food self-sufficiency of the population due to the expansion of households and suburban areas. However, there are also negative characteristics, such as: a decline in purchasing power of the population; imperfect state regulation of foreign food trade; no existing conditions for a stable functioning of the food market as well as for a steady raise in the production of fundamental agricultural commodities, including potatoes.

Rows of empty shelves in European supermarkets, showed in pictures, give rise to concerning thoughts that in the face of a coronavirus outbreak there might not be enough food to sustainably provide to our citizens. Major issues that may occur during quarantine measures are: restrictions on the employees mobility to work in the agriculture and the food industry; increasing number of delays of the food containers, which causes goods damage; excessive food quality control, which can delay delivering and leave the population without the necessary products, moreover, cause an extreme price augmentation.

Agrarian Ukraine, where consumers and businesses experience both booming product sales and crises related to the shortages of food markets, has spent the first month of quarantine avoiding empty shelves in the stores and the fear of hunger. The increase in demand for food products has led to the augmentation of food retail prices by $1-4 \%$, instead, the business was forced to conquer markets - both in Ukraine and abroad. Grain growers were the first to be significantly affected, as they fell under export restrictions which led to a $70 \%$ decrease in sales abroad. In the horticulture business and animal 
husbandry, the biggest hassle was caused by the shutdown of the local markets, where most products were being sold [12].

Europe is ranked the second highest food security region in the world after North America, according to the 2019 Global Food Security Index (GFSI). High incomes, low poverty, stable food retail prices and robust agricultural financing systems make Europe remain at a high-ranking position. Social protection also provides food security for vulnerable segments of people along with the financial support for the state, which is guaranteed in almost all countries in the region.

Nonetheless, the crisis in the health-care field, which has emerged due to the COVID-19 outbreak, has made our seemingly strong food system very susceptible. So now, as never before, it is important for Ukraine to work on its weaknesses and focus on educational support and innovation, allowing farmers to continue their improvement.

GFSI, developed by The Economic Intelligence Unit with the support of Corteva Agriscience, examines the state of food systems in 113 countries, including 26 European countries. The index is based on a thorough analysis of the impact on food security of such factors as provision and quality of food, nutritional diet value, availability of natural resources and sustainability [13].

Despite the European high-performance rates, the 2019 index points to a significant contrast between Western and Eastern Europe, in particular Ukraine and Serbia, which are falling behind in terms of food provision, quality and security [14].

Ukrainian agricultural exports are one of the largest in the world. During the global coronavirus pandemic, Ukraine`s products will play a major role in food security around the world. At the same time, Ukraine is a net exporter, which means that it produces more than it consumes. Ukrainian agrarian industry feeds the world by exporting sunflower oil and corn. Yet, foreign wheat trade should be done attentively, so it does not lead to shortages in the country 
while some traditional food products do not cover demand by their industry. However, due to the spread of the coronavirus, the increasing number of patients and the implementation of quarantine measures, the global food system in all regions will be subjected to many challenges and pressure in the matter of next few weeks. There already are noticeable difficulties in the logistics relating to the food displacement. Furthermore, the coronavirus pandemic affects the livestock sector because of the reduction animal feed and the downsizing of the slaughterhouses capacity.

Conclusions. An important condition for providing food security is the consistent implementation of the interrelated organizational, economic, legislative, administrative and social measures to manage it at the regional and state levels. The combination of state regulation of agro-industrial production with the use of its internal reserves on the basis of their adaptation to the rapidly changing economic conditions will lead to a significant increase in the level of food security both in individual regions and in the country as a whole.

\section{REFERENCES}

1. Transforming our world: the 2030 Agenda of Sustainable Development (2015). Resolution adopted by the General Assembly on 25 September 2015. un.org. Retrieved from

https://www.un.org/en/ga/search/view doc.asp?symbol=A/RES/70/1 English].

2. Volchenko, N. V. (2014). Prodovolcha bezpeka: teoretychni aspekty ta realii sohodennia [Food security: theoretical aspects and realities of today]. Systema natsionalnoho menedzhmentu $v$ konteksti intehratsiinoho vymiru National management system in the context of integration dimension (pp. 3857). Sumy: PP Vinnychenko, FOP Lytovchenko [in Ukrainian]. 
3. Haydutskyy, P. I. (2005). Ukrayini potribna nova ahrarna polityka [Ukraine needs a new agricultural policy]. Ekonomika APK - The Economy of Agro-Industrial Complex, 10, 3-7 [in Ukrainian].

4. Kuzo, R. M. (2015). Prodovolcha bezpeka yak priorytet ahrarnoi polityky [Food security as a priority in agricultural policy]. Suchasni vyklyky prodovolchoi bezpeky - Modern food security challenges: Proceedings of the Round Table. Lviv: Lvivskyi NAU, 38-41. [in Ukrainian].

5. Lypchuk. V. V. (2015). Suchasni vyklyky prodovolchoi bezpeky [Modern challenges of food security]. Suchasni vyklyky prodovolchoi bezpeky - Modern food security challenges: Proceedings of the Round Table. Lviv: Lvivskyi NAU, 4-6. [in Ukrainian].

6. Paskhaver, B.I. (2014). Suchasnyi stan prodovolchoi bezpeky [The current state of food security]. Ekonomika APK - The Economy of AgroIndustrial Complex, 4, 5-12 [in Ukrainian].

7. Sabluk, P.T., Kaletnik, H.M., Kvasha, S.M., Vlasov, V.I., \& Lysak, M.A. (2011). Natsionalna doktryna prodovolchoi bezpeky Ukrainy (proekt) [National Doctrine of Food Security of Ukraine (draft)]. Ekonomika APK - The Economy of Agro-Industrial Complex, 8, 3-11 [in Ukrainian].

8. Syrotiuk. H. V. (2015) Prodovolcha bezpeka - skladova ekonomichnoi bezpeky [Food security - economic security component]. Suchasni vyklyky prodovolchoi bezpeky - Modern food security challenges: Proceedings of the Round Table. Lviv: Lvivskyi NAU, 64-67 [in Ukrainian].

9. Postanova Verkhovnoi Rady Ukrainy Pro pryiniattia za osnovu proektu Zakonu Ukrainy pro prodovolchu bezpeku Ukrainy. [Resolution of the Verkhovna Rada of Ukraine On Adoption of the Bill of Ukraine on Food Security of Ukraine as the Basis]. (n.d.). zakon3.rada.gov.ua. Retrieved from http: zakon3.rada.gov.ua/laws/ show/3498-vi [in Ukrainian].

10. Ulianchenko, A. V., \& Prozorova, N.V. (2014). Prodovolcha bezpeka osnova natsionalnoi bezpeky derzhavy [Food security - the basis of national 
security of the state]. congressworld.com.ua. Retrieved from http://congressworld.com.ua/blog article.php?id=5 [in Ukrainian].

11. Shevchenko, N. O. (2011). Prodovolcha bezpeka yak politychnyi ta ekonomichnyi priorytet derzhavy. [Food security as a political and economic priority states]. Investytsiyi: praktyka ta dosvid. - Investment: practice and experience, 3, 111-113 [in Ukrainian].

12. Koronavirus-2020 ta kharchova bezpeka: chy bude ukraina $\mathrm{Z}$ prodovolstvom, a biznes iz hryvneiu [Coronavirus 2020 and Food Security: Will Ukraine Be Food and Business with Hryvnia]. agropolit.com. Retrieved from https://agropolit.com/spetsproekty/721-koronavirus-2020-ta-harchova-bezpekachi-bude-ukrayina-z-prodovolstvom-a-biznes-z-grivneyu [in Ukrainian].

13. Teslenko, Ihor (2020). Shcho my budemo yisty? Chy zahrozhuiut Ukraini problemy z postachanniam produktiv u period pandemii [What are we going to eat? Does Ukraine have problems with the supply of products during the pandemic?]. nv.ua. Retrieved from https://nv.ua/ukr/biz/experts/pandemiya-tapostavki-produktiv-chi-zagrozhuyut-ukrajini-problemi-z-prodovolchoyubezpekoyu-novini-ukrajini-50081697.html [in Ukrainian].

14. The economist intelligence unit: the global food security index 2018 . https://gtmarket.ru/ratings/global-food-security-index/info [in English].

Стаття надійшла до редакиії 27.03.2020 